\title{
Penggunaan Ayat-Ayat Al-Qur’an Dalam Ritual Rebo Wekasan \\ Studi Living Qur'an di Desa Sukoreno Kec. Kalisat Kab. Jember
}

\author{
Umi Nuriyatur Rohmah \\ STIQ Walisongo Situbondo \\ umi.nuriyah25@gmail.com
}

\begin{abstract}
Abstrak, This article highlights about using Qur'anic verses in the society's ritual called Rebo Wekasan in Sukoreno. Rebo Wekasan is the annual ritual that celebrated by Sukreno's people. This ritual is celebrated on the last Wednesday of Shafar. This ritual aims refusing the unlucky things that believed sent down on that day. This ritual usings some Qur'anic verses, when praying tola' bala' and making the holy water. This article focuses on practicing and meaning of using Qur'anic verses in Rebo Wekasan. This article used descriptive qualitative methods with etnograph's approach using Karl Manheim's sociology of science theory. This articles shows that there are some surahs and verses of Qur'an that used in Rebo Wekasan when praying tala' bala', i.e.: Surah al-Kausar, al-Ikhlas \}, al-Falaq, and al-Nas. When making the holy water the verses that used are Yasin verse 58, al-S \{ affat verse 130 - 131, al-Zumar verse 73, al-Ra'd verse 24, and al-Qadr verse 5. Based on Mannheim's theory, There are three meanings of using the Qur'anic verses in this ritual, those are; objective as a tradition, expressive as refusing unlucky things (bala'), and documenter as a culture.
\end{abstract}

Keywords: Using Qur'anic verses, Ritual, Rebo Wekasan, Living Qur'an

\section{A. Pendahuluan}

Al-Qur'an di samping dianggap sebagai kitab suci, juga merupakan kitab petunjuk. Al-Qur'an selalu dijadikan pedoman dalam kehidupan sehari-hari umat Islam dalam konteks apapun yang melingkupi kehidupan manusia. Islam dengan al-Qur'an sebagai pokok ajarannya, senantiasa mampu memperbaharui diri dan dinamis dalam merespon perubahan zaman. Selain itu, juga mampu berdialog dengan kondisi masyarakat yang berbeda-beda. Dengan demikian tidak heran jika al-Qur'an selalu hidup dan tumbuh dalam kehidupan masyarakat. 
Indonesia dikenal sebagai bangsa yang mempunyai beraneka ragam budaya dari warisan nenek moyang yang selalu dijaga dengan kuat. Selain itu, sebagai negara yang mayoritas beragama Islam, umat Islam Indonesia memiliki keyakinan yang kuat akan kesakralan al-Qur'an. Dua hal tersebut bertemu dan berkualisi membangun kebudayaan baru, yang tidak menghilangkan identitas dua kebudayaan sebelumnya. Dari akulturasi tersebut, banyak kita temukan produk interaksi muslim Indonesia dengan al-Qur'an, seperti yang tertuang dalam ritual keagamaan, kesenian, peribadatan maupun kegiatan sehari-hari.

Adapun salah satu ritual keagamaan yang berlangsung di masyarakat adalah ritual Rebo wekasan. Ritual ini sudah menjadi tradisi tahunan khususnya di daerah Jawa, karena ritual ini merupakan tradisi turun temurun dari nenek moyang. Ritual ini dilaksanakan pada hari rabu terakhir di bulan Shafar $^{l}$. Rebo wekasan juga disebut dengan rebo pungkasan atau rebo kasan. istilah Rebo wekasan bisanya sering digunakan oleh masyarakat Jawa Timur, sedangkan istilah rebo pungkasan atau rebo kasan banyak digunakan oleh masyarakat Jawa Tengah dan Jawa Barat. Istilah rebo kasan sebagian mengasumsikan kata kasan merupakan penggalan dari kata pungkasan yang berarti akhir dengan mambuang suku kata depan menjadi kasan. Sebab rebo kasan adalah hari rabu yang terakhir dari bulan Shafar. Rebo wekasan merupakan ritual yang dilaksanakan sebagai bentuk rasa syukur kepada Allah dan sekaligus memohon pada Allah agar dijauhkan dari segala bencana. Masyarakat jahiliah kuno termasuk bangsa Arab sering mengatakan bahwa bulan Shafar merupakan bulan sial, ${ }^{2}$ karena dipercayai pada bulan Shafar Allah menurunkan banyak malapetaka.

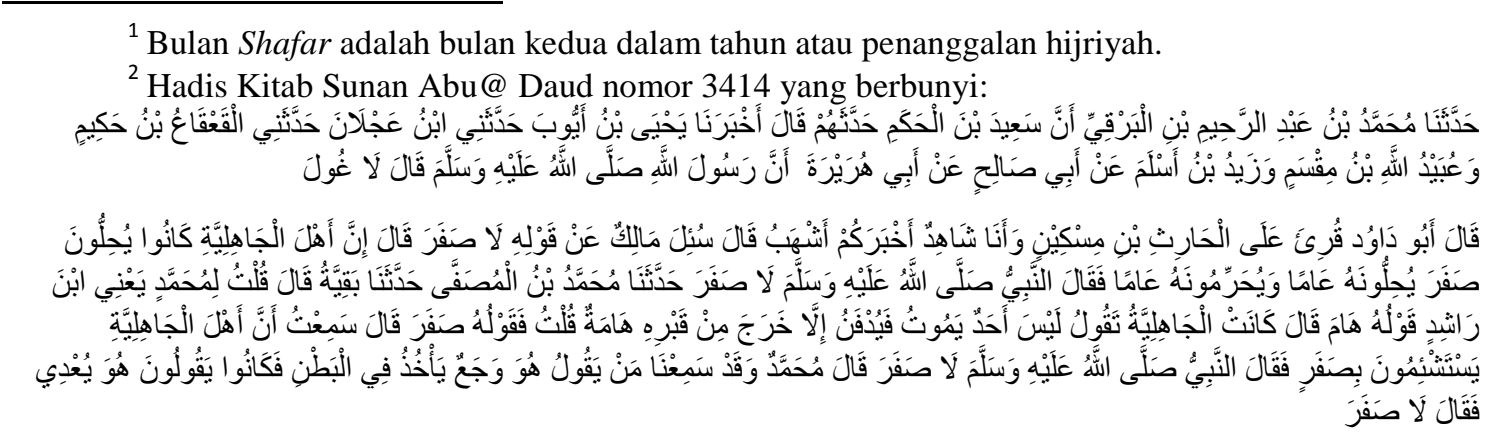

Telah menceritakan kepada kami Muhammad bin Abdurrahim bin Al Barqi bahwa Sa'id bin Al Hakam telah menceritakan kepada mereka, ia berkata; telah mengabarkan kepada kami Yahya bin Ayyub telah menceritakan kepadaku Ibnu 'Ajlan telah menceritakan kepadaku Al Qa'qa' bin Hakim dan 'Ubaidullah bin Miqsam dan Zaid bin Aslam dari Abu Shalih dari Abu Hurairah, bahwa Rasulullah 
Terkait praktik ritual Rebo wekasan, setiap daerah memiliki praktik yang berbeda-beda. Ritual Rebo wekasan di Jawa Timur, tepatnya di Desa Sukoreno Kec. Kalisat Kab. Jember dilaksanakan dengan menuliskan ayat-ayat al-Qur'an di atas piring porselen putih, kemudian dicelupkan kedalam air, dan diminum, yang berkhasiat sebagai pencegah dari bencana - bencana yang turun pada hari tersebut. Masyarakat setempat percaya bahwa air yang telah ditulisi ayat al-Qur' an dapat menjauhkan mereka dari segala bahaya. Disebabkan karena al-Qur'an merupakan kitab suci yang “ multi fungsi ".

Dalam praktiknya, ayat-ayat al-Qur'an disamping sebagai bacaan yang mempunyai nilai ibadah, sekaligus sebagai referensi pokok kaum muslimin dalam menghadapi problematika sosial dan transendental. Al-Qur'an sejak masa Nabi juga digunakan sebagai sarana untuk mencegah atau memusnahkan sihir jahat dan menyembuhkan berbagai penyakit. Hal ini yang menjadi salah satu pedoman atau kepercayaan masyarakat di Desa Sukoreno, bahwa ayat-ayat al-Qur'an dapat mencegah dari segala bahaya atau bencana. Penggunaan ayat-ayat al-Qur'an dalam ritual Rebo wekasan merupakan respon masyarakat terhadap teks al-Qur'an yang dapat dijumpai dalam kehidupan sehari-hari. Teks al-Qur'an yang hidup dimasyarakat itulah yang disebut Living Qur'an. ${ }^{3}$

shallallahu 'alaihi wasallam bersabda: "Tidak ada ghul (yang dapat menyesatkan seseorngpun)." Abu Daud berkata; telah dibacakan di hadapan Al Harits bin Miskin -sementara aku menyaksikan- telah mengabarkan kepada kalian Asyhab ia berkata; Malik pernah ditanya mengenai sabda beliau 'Tidak ada shafar', maka ia menjawab, "Sesungguhnya orang-orang jahiliyah dahulu menghalalkan bulan Shafar satu tahun dan mengharamkannya satu tahun. Kemudian Nabi shallallahu 'alaihi wasallam bersabda: 'Tidak ada shafar'. Telah menceritakan kepada kami Muhammad bin Al Mushaffa telah menceritakan kepada kami Baqiyyah ia berkata, "Aku tanyakan kepada Muhammad bin Rasyid, "Bagaimana dengan kata 'haam'? Ia menjawab, "Orang-orang jahiliyah dulu mengatakan, 'Tidaklah orang yang meninggal kemudian dikubur melainkan keluar serangga berbisa dari kuburnya'. Aku tanyakan lagi, "Bagaimana dengan kata, 'Shafar'? Ia menjawab, "Aku pernah mendengar bahwa orang-orang jahiliyah menisbatkan kesialan kepada bulan Shafar." Kemudian Nabi shallallahu 'alaihi wasallam bersabda: "Tidak ada shafar." Muhammad berkata, "Aku mendengar orang yang mengatakan, 'Itu adalah suatu penyakit yang bertempat di dalam perut. Dahulu mereka mengatakan, 'Penyakit tersebut menular'. Maka beliau bersabda: "Tidak ada shafar."

Hadis Riwayat Abu@ Daud, SunanAbu@Daud, Kita>b Pengobatan, Bab Penjelasan T\{iyarah, No. 3414, CD Lidwa 9 Kitab Imam.

${ }^{3}$ Shahiron Syamsyudin, “ Ranah-Ranah dalam Studi al-Qur'an” Pengantar dalam Shahiron Syamsudin (ed.), Metodologi Penelitian Living Qur'an dan Hadits (Yogyakarta: TH- Press dan Teras, 2007), hlm. xi-xiv. 
Berangkat dari fenomena ini, penulis tertarik untuk meneliti serta mengkaji ritual Rebo wekasan di Desa Sukoreno. Untuk mengerucutkan pembahasan sehingga fokus permasalahan dalam tulisan ini dapat lebih terarah, maka penulis hanya fokus pada pembahasan mengenai praktik ritual Rebo wekasan dan makna dari penggunaan ayat-ayat al-Qur'an dalam ritual tersebut.

\section{B. Sejarah Ritual Rebo Wekasan di Desa Sukoreno}

Ritual Rebo wekasan termasuk warisan dari generasi sebelumnya dan merupakan bagian dari aktivitas kehidupan masyarakat desa Sukoreno yang sudah berurat akar dalam kehidupan sehari-hari. Ritual ini dilaksanakan setiap hari rau terakhir bulan shafar. Rebo wekasan merupakan ritual yang mempunyai nuansa religious sekaligus budaya yang sudah berlangsung selama bertahun-tahun. Terkait alasan dan penyebab munculnya kepercayaan ini tidak ada yang mengetahui secara pasti. Namun menurut Pak Hasyim Asy'ari ${ }^{4}$ selaku tokoh masyarakat sekaligus pemimpin ritual Rebo wekasan bahwa keterangan mengenai ritual Rebo wekasan terdapat dalam kitab "Tajwid Madura". 5 Kitab ini berbahasa Madura, karena pengarangnya berasal dari Kecamatan Banyu Anyar Kabupaten Pamekasan Madura. ${ }^{6}$

Dalam kitab tersebut disebutkan:

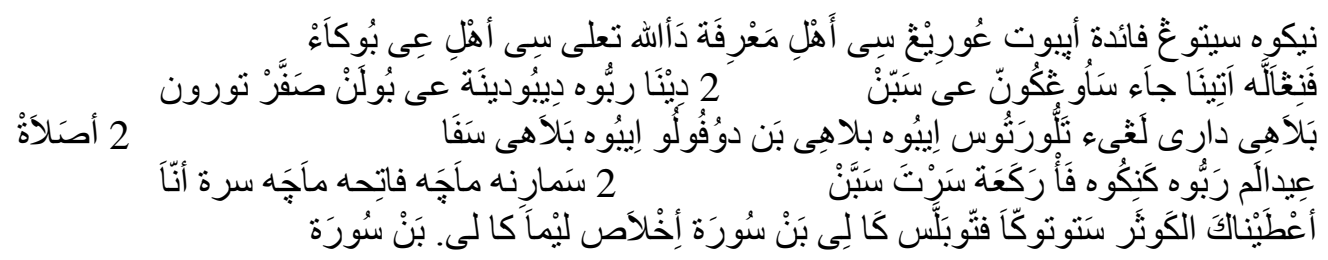

${ }^{4}$ Bapak Hasyim Ays'ari yang akrab dipanggil pak Asy'ari adalah salah satu tokoh masyarakat di Desa Sukoreno. Beliau juga seorang guru ngaji yang mempunyai banyak santri, dan masyarakat Sukoreno sangat ta'dim dan patuh terhadapnya.

${ }^{5}$ Kitab ini merupakan terjemah sekaligus salinan kitab yang ditulis oleh KH. Abdul Hami>d bin Is|bat. Dalam muqaddimah, penulis kitab tidak menyebutkan nama kitab yang dikarang oleh KH. Abdul Hami >d bin Is|bat, Penulis menamai kitab salinan ini dengan nama Tajwid Madura, hal ini dijelaskan dalam penutup kitab. Penamaan kitab Tajwid Madura adalah sebutan yang berasal dari pelaku ritual Rebo wekasan di Desa Sukoreno. Akan tetapi judul kitab yang terdapat di halaman sampul adalah ( فَنَيكَا

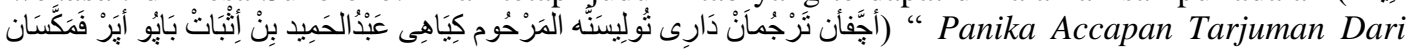
Tulisanah Almarhum KH. Abdul Hami>d Bin Is bat Banyu Anyar Pamekasan” yang artinya adalah " Ini Adalah Salinan Terjemah dari Kitab Almarhum KH. Abdul Hami>d Bin Is $\}$ bat Banyu Anyar Pamekasan". Untuk mempermudah masyarakat mengingat nama kitab ini, maka masyarakat Sukoreno menyebutnya dengan kitab Tajwid Madura. Kitab ini berisi pedoman-pedoman agama serta ibadah harian seperti; shalat, tatakrama membaca al-Qur'an, tatakrama membaca do'a dan lain-lain.

${ }^{6}$ Wawancara dengan pak Asy'ari sebagai pemimpin ritual Rebo wekasan, di Sukoreno tanggal 1 Januari 2014. 


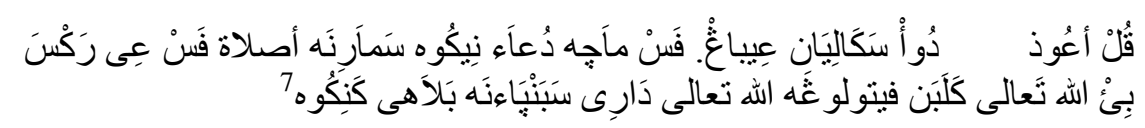

Artinya:

Dalam salah satu faidah disebutkan bahwa, seorang ahli ma'rifat yang dibukakan hatinya oleh Allah mengatakan, "sesungguhnya setiap hari rabu terakhir di bulan Shafar, Allah menurunkan 320.000 malapetaka dari langit. Barang siapa yang menunaikan shalat di hari itu sebanyak empat raka'at, dan tiap raka'at setelah membaca surah al-fatihah, membaca surat inna@ a'toina@ka al-kausar sebanyak tujuh belas kali, kemudian surat al-ikhlas sebanyak lima kali, dan surat qul a'uz\#u bi rabbi al falaq dan qul a'uz\#u bi rabbi al-na\#s satu kali. Kemudian membaca do'a setelah shalat. Barang siapa yang melaksanakan amalan tersebut, maka Allah akan melindunginya dari malapetaka yang turun di hari tersebut."

Keterangan di atas menjelaskan tentang anjuran atau amal-amalan pada hari rabu terakhir bulan shafar. Karena diyakini, Allah akan menurunkan banyak musibah pada hari tersebut. Menurut keyakinan arab kuno, bulan shafar diyakini sebagai bulan sial. Sebagaimana dijelaskan dalam hadis Abu Daud no. 3414. Al-Qur'an juga menjelaskan perihal hari nahas yang terdapat dalam QS. al-Qamar: 19 :

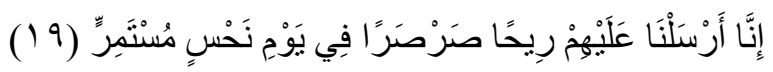

Artinya:

Sesungguhnya Kami telah menghembuskan kepada mereka angin yang sangat kencang pada hari nahas yang terus menerus.

Ayat di atas menjelaskan bahwa Allah menurunkan musibah pada hari nahas (hari sial). Dari ayat tersebut dapat diketahui bahwa hari sial memang ada. Dan kebanyakan masyarakat meyakini bahwa hari sial tersebut jatuh pada hari rabu terakhir bulan shafar. Sebagaimana keterangan dalam kitab tajwid madura, bahwa pada hari tersebut akan diturunkan banyak malapetaka.

Kitab Tajwid Madura merupakan salah satu kitab acuan pak Asy'ari dalam pelaksanaan ritual Rebo wekasan. Kitab tersebut beliau dapatkan ketika nyantri di P.P. Miftahul Ulum Lumajang. Berdasarkan penjelasan pak Asy’ari, kitab Tajwid Madura berasal dari kota Banyu Anyar Pamekasan Madura. Pendiri P.P Miftahul Ulum

${ }^{7}$ Abdul Hamid Baqir, Ringkasan terjemah dari karangan KH. Abdul Hami $>$ d bin Is $\mid$ bat (Madura: Dar al-Taqafi, 1980), hlm. 90. 
mendapatkan kitab tersebut dari saudaranya di Madura, karena beliau masih keturunan keluarga Banyu Anyar. Kitab Tajwid Madura ditulis oleh KH. Abdul Hamid Baqir yang merupakan cucu dari pengarang kitab asli, yaitu KH. Abdul Hamid bin Isbat. Jika ditelusuri dari silsilah keluarga, KH. Abdul Hamid bin Isbat merupakan keturunan dari Sunan Giri. ${ }^{8}$ Diketahui bahwa Sunan Giri merupakan orang pertama yang melaksanakan ritual Rebo wekasan di Jawa Timur.

Dari hasil penelusuran yang penulis lakukan, penulis menemukan kitab bernama Kanzun Najah karya Abdul Hamid bin Muhammad Ali Qudsi. ${ }^{9}$ Kitab ini merupakan kitab acuan dari kitab Tajwid Madura. Kandungannya membicarakan berbagai amalan wirid, doa, zikir dan beberapa praktik ritual, misalnya ritual yaumul 'Asyura, Rajab, Muharram, Rebo wekasan dan lain-lain. Di dalamnya dijelaskan secara rinci tentang ritual Rebo wekasan. Pelaksanaan ritual Rebo wekasan di P.P. Banyu Anyar hampir sama dengan praktik yang dilaksanakan di desa Sukoreno. Hanya saja, sebelum acara ritual dimulai, sang Kyai mengajarkan kepada santri perihal pengertian, tata cara, serta manfaat ritual Rebo wekasan. Penjelasan tersebut merujuk kepada dua kitab yaitu kitab Kitab Tajwid Madura dan kitab Kanzun Najah. ${ }^{10}$ Sedangkan di desa Sukoreno, pak Asy'ari menjelaskan kepada masyarakat tentang pengertian dan khasiat Rebo wekasan pada hari jum'at menjelang ritual Rebo wekasan di Masjid melalui jama'ah jum'at.

Dalam kitab Tajwid Madura dijelaskan bahwa setiap hari Rabu terakhir bulan Shafar Allah menurunkan 320.000 malapetaka. Barangsiapa yang menunaikan shalat pada hari itu sebanyak empat rakaat, dan setiap rakaat setelah al-Fatihah membaca surat al-Kaustar sebanyak tujuh belas kali, surat al-Ikhlas sebanyak lima kali, dan surat mu'awidhatain satu kali, kemudian membaca do'a setelah shalat dan membuat jimat, maka Allah akan melindunginya dari malapetaka yang turun pada hari tersebut. Terkait praktik ritual Rebo wekasan, hanya sebagian masyarakat yang mengetahui bahwa dalam

\footnotetext{
${ }^{8}$ Lembar silsilah keturunan Sunan Giri penulis peroleh dari koleksi silsislah para wali milik pak Asy’ari.

9 Abdul Hamid bin Muhammad Ali Qudsi adalah seorang ulama Makkah. Lahir di Makkah, $1280 \mathrm{H}$ dan wafat pada tahub $1334 \mathrm{H}$. Beliau hijrah ke Indonesia pada saat perang dunia ke dua. Di Indonesia, beliau mengajar sekaligus mendirikan madrasah Muhammadiyah. Beliau juga aktif menulis sehingga menerbitkan majalah salafiyah al-Mir'ah al-Muhammadiyah. Keterangan ini terdapat dalam muqaddimah kitab Kanzun Najah (Makkah: Mathba'ah At-Taraqqil Majidiyah al-Usmaiyah, 1330), hlm. 10 .

${ }^{10}$ Wawancara dengan Nailur Rahman, alumni P.P. Banyu Anyar Pamekasan Madura, di Yogyakarta, tanggal 3 Juni 2014.
} 
ritual dianjurkan melaksanakan shalat empat raka'at. Mayoritas masyarakat Sukoreno hanya melakukan praktik membuat dan meminum air jimat, karena praktik tersebut sudah ada dan dilaksanakan oleh masyarakat Sukoreno sebelum pak Asy’ari memimpin.

\section{Proses Pelaksanaan Ritual Rebo Wekasan}

Pelaksanaan ritual rebo wekasan di Desa Sukoreno mengalami perkembangan. Sebelum pak Asy'ari menjadi pemimpin ritual, pelaksanaan ritual rebo wekasan sangat sederhana, yaitu membuat air jimat dan meminumnya. Air jimat tersebut yang diyakini sebagai penolak bala'. Isi dari jimat tersebut adalah potongan-potongan ayat al-Qur'an yang dituliskan pada piring porselen atau kertas putih, setelah jimat selesai ditulis, pemimpin ritual meleburkan jimat tersebut ke dalam air. Kemudian masyarakat meminum dan membawa sebagian air dengan menggunakan tempat air yang telah mereka bawa sebelumnya. Selain diminum, air jimat juga dimasukkan ketempat-tempat air, seperti kendi, gentong, sumur, kamar mandi, dan lain sebagainya.

Seiring berkembangnya zaman serta bergantinya pemimpin ritual, pelaksanaan ritual pun berubah, tanpa mengurangi esensi dari ritual rebo wekasan yang selama ini dijalankan. Pelaksanaan ritual yang dipimpin oleh pak Asy'ari mengikuti tata cara yang telah disebutkan dalam kitab Tajwid Madura. Setiap melaksanakan ritual rebo wekasan, pak Asy'ari selalu mengajar dan mengingatkan tentang pengertian rebo wekasan beserta tatacara pelaksanaannya. Adapun proses pelaksanaan ritual rebo wekasan adalah sebagai berikut:

\section{a. Shalat tala' bala'}

Praktik yang pertama adalah shalat tala' bala'. Sebelum melaksanakan shalat, pak Asy'ari menuliskan niat dan tata cara shalat pada papan tulis, sambil menjelaskan kepada para santri. Penjelasan yang ditulis menggunakan bahasa Madura. Shalat tala' bala' berjumlah empat raka'at yang dilakukan dengan dua salam. Setiap raka'at setelah membaca surat al-Fatihah membaca surat al-Kaus|ar sebanyak tujuh belas kali, kemudian surat al-Ikhlas sebanyak lima kali, dan surat al-Fala>q satu kali, serta an$\mathrm{Na}>\mathrm{s}$ satu kali. Dilaksanakan dengan tidak berjama'ah. Setelah selesai melaksanakan shalat tala' bala', kemudian membaca doa' yang dipimpin oleh pak Asy’ari. 
b. Membaca doa bersama

Setelah selesai melaksanakan shalat, kemudian membaca doa yang dipimpin pak Asy'ari dan diikuti oleh para santri. Doa tersebut dibaca sebanyak tiga kali. Adapun teks doanya adalah sebagai berikut:

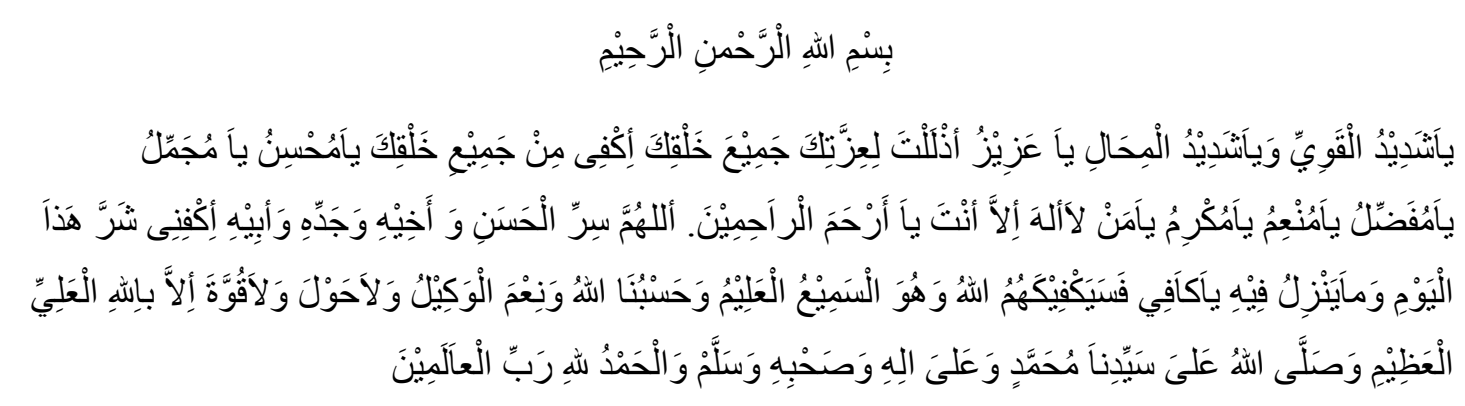

Artinya:

Dengan menyebut nama Allah yang Maha Pengasih dan Maha Penyayang

Wahai zlat yang Maha Kuat dan menguasai tipu daya, Maha Mulia engkau karna ke lemah lembutan-Mu kepada semua mahluk-Mu, cukupkanlah dari semua mahluk-Mu, wahai z\{at yang memiliki kebaikan, keindahan, dan keutamaan, wahai z\{at pemberi nikmat dan dermawan. Tidak ada Tuhan selain engkau, wahai Tuhanku yang maha pengasih dan penyayang. Lindungilah aku dari kejelekan hari ini serta sesuatu yang turun di dalamnya. Maka Allah akan memberi kecukupan kepadamu dan mereka. Dia Maha Mendengar dan sebaik-baiknya penolong. Tidak ada kekuatan yang menandingi-Nya. Semoga Allah mencurahkan keselamatan untuk Nabi Muhammad, keluarganya dan para sahabatnya. Segala puji bagi Allah Tuhan segala alam.

c. Membuat Air Jimat

Setelah do'a selesai dibacakan bersama-sama, pak Asy'ari mempersiapkan piring untuk menulis jimat. Jimat ditulis pada piring porselen putih tak bergambar dan ditulis dengan tinta spidol. Jumlah piring yang disediakan sebanyak tujuh buah, spidol yang disediakan sebanyak sepuluh buah. Pak Asy'ari memerintahkan lima santri untuk menulis jimat dalam masing-masing piring. Dua piring ditulis pak Asy'ari pada malam menjelang Rebo wekasan, dan penulisan jimat dipandu oleh pak Asy'ari. Setelah jimat selesai ditulis, jimat dileburkan ke dalam wadah air yang sudah disediakan oleh pak Asy'ari. Namun sebelum meleburkannya, pak Asy'ari terlebih dahulu membacakan ayat-ayat yang terdapat dalam jimat tersebut, yang kemudian diikuti oleh masyarakat. Setelah jimat tersebut dileburkan kedalam air, kemudian air tersebut dibagikan kepada masyrakat untuk diminum. 
Pelaksanaan ritual rebo wekasan di atas, yang meliputi shalat tala' bala' dan penulisan jimat dilakukan oleh santri pak asy'ari. Sebagian masyarakat memahami praktik ritual rebo wekasan hanya membuat dan meminum air jimat. Hal ini dikarenakan masyarakat masih mengikuti ritual lama atau ritual nenek moyang. Masyarakat meyakini bahwa air jimat yang telah dileburi tulisan al-Qur'an dapat mencegah dari malapetaka yang turun pada hari tersebut.

Prosesi pembuatan air jimat merupakan pelaksanaan yang paling urgen menurut sebagian masyarakat, karena prosesi ini merupakan warisan dari leluhur. Akan tetapi menurut penjelasan pak Asy'ari, semua pelaksanaan ritual dalam ritual rebo wekasan, baik itu shalat tala' bala' maupun pembutan jimat adalah urgen. Perihal pemahaman masyarakat tentang air jimat, pak Asy'ari tidak begitu mempermasalahkan. Sebagaimana penjelasan pak Asy'ari ketika ditemui di kediamannya:

Banyak masyarakat Sukoreno yang belum tau perihal shalat tala' bala', karena tradisi dari nenek moyang ketika rebo wekasan hanya membuat air jimat saja, bagi saya shalat dan membuat air jimat adalah sama pentingnya. Perihal orang yang tidak melakukan shalat tala' bala' tidak apa-apa. Saya mengibaratkannya seperti do'a. ibaratkan saya yang memimpin doa sedangkan masyarakat yang mengamininya. $^{11}$

\section{Al-Qur'an dalam Ritual Rebo Wekasan}

\section{Ayat-ayat al-Qur'an dalam ritual rebo wekasan}

Dalam praktik ritual rebo wekasan, terdapat beberapa surat dan potongan ayat yang digunakan. Penggunaan ayat-ayat al-Qur'an, terletak pada dua pelaksanaan yaitu:

a. Ayat-ayat al-Qur'an dalam shalat tala' bala'

Terdapat empat surat yang dibaca dalam shalat tala' bala' yaitu surat al-Kautsar, al-Ikhlas, al-Fala>q, dan an-Na@s. Setiap surat dibaca dengan jumlah yang berbedabeda. Surat al-Kaus|ar dibaca sebanyak tujuh belas kali, surat al-Ikhlas sebanyak lima kali dan surat al-Fala@q dan an-Na>s masing-masing satu kali. Menurut pak Asy'ari, surat yang dibaca dalam shalat tala'bala' merupakan ketentuan dari orang yang pertama melakukan ritual rebo wekasan serta anjuran dalam kitab Tajwid Madura. Namun surat-

\footnotetext{
${ }^{11}$ Wawancara dengan bapak Asy’ari, tanggal 1 Januari 2014.
} 
surat tersebut boleh diganti dengan surat lain, karena pembacaannya tidak wajib, hanya saja yang lumrah dibaca dalam shalat tala' bala' adalah ke empat surat di atas.

Mengenai pembacaan bekali-kali, menurut pak Asy'ari itu hanyalah anjuran saja, dibaca berkali-kali karena kita membutuhkan 'kebagusan' 12 yang banyak. Semakin banyak membacanya, maka semakin banyak pula kebagusan yang didapat. Jika dibaca hanya satu kali, maka diperbolehkan. Karena pembacaan surat tersebut hanya sebuah anjuran bukan kewajiban.

b. Ayat-ayat al-Qur'an dalam jimat

Tulisan ayat al-Qur'an yang terdapat dalam jimat terdiri dari beberapa potongan ayat dari beberapa surat, yaitu:

1. Surat Yasin ayat 58

2. Surat Al-Shaffat ayat $79-80$

3. Surat Al-Shaffat ayat 109-110

4. Surat Al-Shaffat ayat 130-131

5. Surat Az-Zumar ayat 73

6. Surat Al-Ra'd ayat 24

7. Surat Al-Qadr ayat 5

Ayat-ayat di atas merupakan ayat kisah para Nabi, yaitu kisah Nabi Nuh, Nabi Ibrahim, dan Nabi Ilyas yang mendapatkan keselamatan dari Allah karena kesabaran mereka. Sebelum tulisan ayat, terdapat lafaz do'a yang mengawali. Lafaznya sebagai berikut:

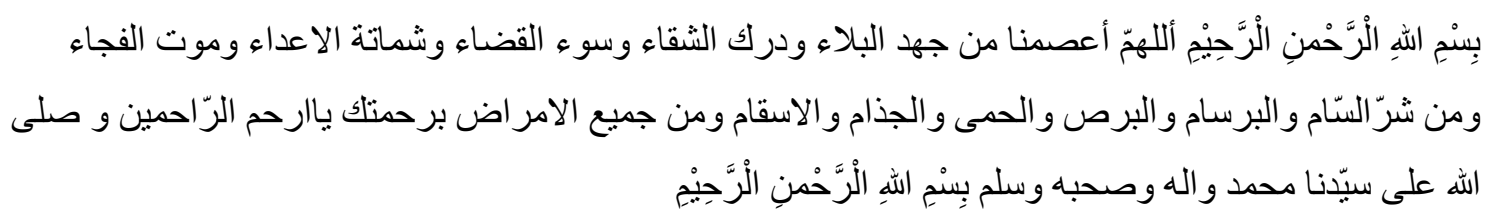

Artinya:

Dengan menyebut nama Allah yang Maha Pengasih dan Penyayang. Jauhkanlah kami dari segala musibah, dan turunnya kesialan, dan segala kejahatan, dan perasaan gembira terhadap bencana yang menimpa orang lain, serta kematian yang menyergap. Jauhkan pula dari kematian yang su'ul khatimah, dan dari segala

\footnotetext{
${ }^{12}$ Kebagusan juga diartikan dengan pahala dan kebaikan.
} 
penyakit, kusta, demam, lepra dan mual. Dengan kasih sayang-Mu wahai z\{at yang Maha pengasih dan penyayang. Semoga Allah mencurahkan keselamatan kepada Nabi Muhammad, keluarga serta para sahabatnya. Dengan menyebut nama Allah yang Maha Pengasih dan Penyayang.

Selain ayat-ayat dan do'a di atas, ada beberapa simbol angka yang dituliskan sebagai jimat, adapun simbol tersebut sebagai berikut:

\begin{tabular}{|c|c|c|}
\hline بعباده & لطيف & الله \\
\hline 84 & 129 & 66 \\
\hline أمفاء & سغاء & دوأ \\
\hline 75 & 93 & 111 \\
\hline تلؤُ & ليماء & فتؤ \\
\hline 120 & 57 & 102 \\
\hline بلؤ & ستو & انم \\
\hline
\end{tabular}

Tulisan jimat ditulis secara melingkar pada piring porselen sebagaimana keterangan dalam kitab Tajwid Madura. Lebih jelasnya, dapat dilihat pada gambar berikut:

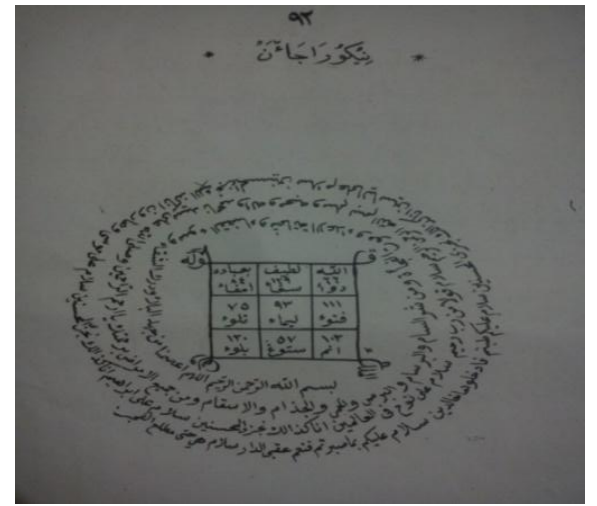

Tulisan Jimat dalam kitab Tajwid Madura.

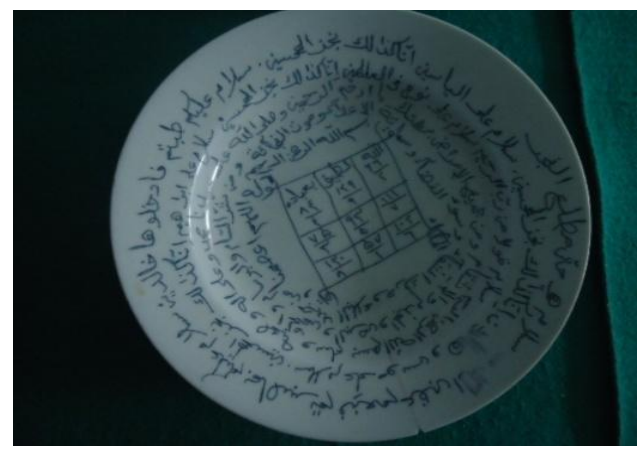

Tulisan jimat dalam piring porselen

\section{Faktor Penggunaan Ayat al-Qur'an dalam Ritual Rebo Wekasan}

a. Memohon Keselamatan

Tidak lepas dari fungsi al-Qur'an sebagai media untuk memohon petunjuk dan keselamatan kepada Allah, hal ini telah menjadi salah satu faktor pendorong untuk selalu menghidupkan al-Qur'an serta menjadikan al-Qur'an bagian dalam kehidupan sehari-hari umat Islam, termasuk masyarakat Desa Sukoreno. Pada pelaksanaan ritual Rebo wekasan terdapat ayat-ayat al-Qur'an yang digunakan didalamnya, seperti surat al-Falaq dan Muawwizatain, akan tetapi masyarakat Sukoreno menyebutnya dengan “ qulhu sedue' " artinya, dua surat qulhu. Masyarakat Sukoreno mengharap keselamatan 
kepada Allah atas segala musibah yang turun pada hari Rebo wekasan. Sebagaimana peristiwa pada masa Nabi, ketika beliau menderita sakit sebelum kematiannnya dengan mengunakan surat muawwiz|atain. ${ }^{13}$ Sebagaimana diungkapkan oleh pak Asy'ari sebagai berikut:

Yang menjadi tujuan pokok diadakan Rebo wekasan adalah untuk memperoleh keselamatan, khususnya keselamatan atas segala musibah yang diturunkan pada hari tersebut. Adanya surat-surat tertentu dalam Rebo wekasan tentunya terdapat keistimewaan tersendiri dalam surat tersebut. Misalnya dalam surat muawwiz|atain, isinya untuk meminta perlindungan pada Allah dari kejelekan setiap mahluk, sihir, serta orang-orang yang dengki. ${ }^{14}$

Dicantumkannya surat-surat al-Qur'an dalam ritual Rebo wekasan adalah sebagai media doa untuk memohon keselamatan.

b. Riwayat dari Ulama Terdahulu

Selain untuk memohon keselamatan, salah satu faktor penggunaan ayat-ayat alQur'an adalah riwayat dari ulama terdahulu. Sebagaimana diungkapkan oleh Yusri, salah satu santri pak Asy'ari juga pelaku ritual Rebo wekasan:

Pembacaan surat-surat al-Qur'an dan tulisan surat al-Qur'an dalam ritualRrebo wekasan merupakan turunan dan sudah lama dilakukan oleh para alim ulama. Tentunya para ulama tidak mungkin asal-asalan mengambil surat dan ayat alQur'an. Mereka pasti sudah mengetahui makna dan kandungan dari ayat tersebut. Kita tau bahwa ulama terdahulu sebelum menentukan sesuatu harus tirakat dulu, jadi tidak mungkin jika mereka asal mengambil ayat al-Qur'an. ${ }^{15}$

\footnotetext{
${ }^{13}$ Sebagaimana tercantum dalam Kitab S\{ahih Muslim nomor 4065 yang berbunyi:

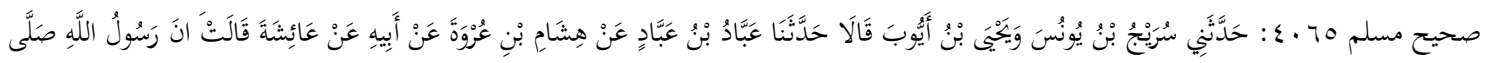

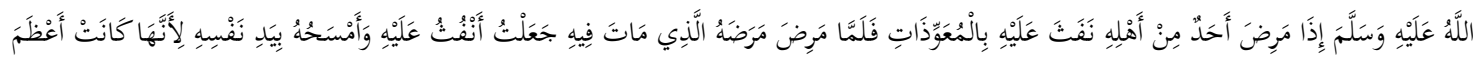

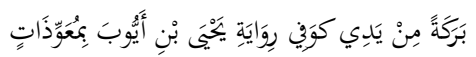

“ Telah menceritakan kepadaku Suraij bin Yunus dan Yahya bin Ayyub keduanya berkata; Telah menceritakan kepada kami 'Abbad bin 'Abbad dari Hisyam bin 'Urwah dari Bapaknya dari 'Aisyah dia berkata; "Apabila salah seorang isteri Rasulullah shallallahu 'alaihi wasallam sakit, beliau tiupkan kepadanya surat-surat mu'awwidzaat. Maka tatkala beliau sakit hampir meninggal, kutiupkan pula kepadanya dan kusapukan tangannya ke tubuhnya, karena tangan beliau lebih besar barakahnya daripada tanganku." Dan di dalam riwayat Yahya bin Ayyub dengan lafazh 'Mu'awwidzat' tanpa alif lam."

Hadis Riwayat Muslim, S\{ahi@@@@@ Muslim, Kitab al-Salam, No. 4065, CD Lidwa 9 Kitab Imam.

${ }^{14}$ Wawancara dengan pak Hasyim Asy’ari, 8 Januari 2014.

${ }^{15}$ Wawancara dengan M. Yusri Zaini, sebagai santri pak Asy’ari sekaligus pelaku ritual rebo wekasan, di Sukoreno tanggal 2 Januari 2014.
} 
Dari penjelasan Yusri, dapat disimpulkan bahwa, penggunaan ayat-ayat alQur'an dalam ritual Rebo wekasan adalah ketentuan dari para ulama terdahulu. Yusri meyakini bahwa ulama terdahulu pasti mempunyai alasan dan mengetahui makna serta fungsi dari ayat-ayat yang digunakan. Pernyataan Yusri senada dengan ungkapan pak Erfan selaku kepala Desa Sukoreno. Beliau mengungkapkan bahwa para ulama tentunya memiliki alasan mengapa mengambil ayat-ayat tertentu, karena mereka merupakan orang-orang berilmu yang dekat dengan Allah. ${ }^{16}$

Dari penjelasan di atas dapat diambil kesimpulan bahwa, pembacaan dan penulisan al-Qur'an adalah praktik yang diterima secara turun temurun. Dan hal ini juga merupakan suatu bukti kepatuhan masyarakat Sukoreno kepada tokoh masyarakat atau ulama.

\section{c. Menjaga Tradisi}

Menurut penjelasan pak Asy’ari, penggunaan surat al-Qur'an selain untuk memohon keselamatan, juga mengikuti tradisi sebelumnya. Karena bacaan al-Qur'an itulah yang biasa digunakan dalam ritual Rebo wekasan. Pak Asy'ari menambahkan bahwa setiap tradisi akan tetap bertahan selama mendatangkan manfaat bagi manusia. Beliau mengumpamakan ritual Rebo wekasan kedalam penjelasan surat al-Ra'd: 17:

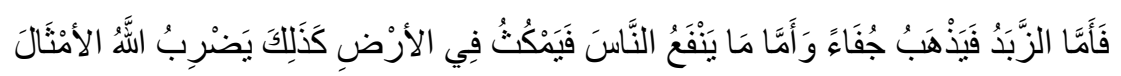

Artinya:

Demikianlah Allah membuat perumpamaan (bagi) yang benar dan yang bathil. Adapun buih itu, akan hilang sebagai sesuatu yang tak ada harganya; Adapun yang memberi manfaat kepada manusia, Maka ia tetap di bumi. Demikianlah Allah membuat perumpamaan-perumpamaan. (Q.S. al-Ra'd: 17)

Mengenai ayat di atas, pak Asy'ari memberi penjelasan sebagai berikut:

Adapun busa, maka hilang dan musnah seperti sesuatu yang tak ada harganya, adapun sesuatu yang bermanfaat bagi manusia, maka akan tetap di bumi. Demikian Allah membuat perumpamaan. Jadi, jika busa terkena air, maka busa itu akan cepat hilang dan musnah seperti sesuatu yang tak berharga. Adapun sesuatu yang dapat memberi manfaat terhadap manusia, maka Allah akan

\footnotetext{
${ }^{16}$ Wawancara dengan Pak Erfan Sahrianto, tanggal 2 Januari 2014.
} 
mempertahankannya. Dan sesuatu yang tidak bermanfaat bagi manusia, ibaratkan busa, yaitu cepat hilang. ${ }^{17}$

Penjelasan di atas memberi kesimpulan bahwa ritual Rebo wekasan merupakan ritual turun temurun yang membawa banyak manfaat bagi manusia, khususnya bagi masyarakat Desa Sukoreno. Hal itu terbukti bahwa ritual tersebut masih tetap dilaksanakan sampai saat ini.

\section{Pemaknaan Masyarakat Sukoreno terhadap Penggunaan Ayat-ayat al- Qur'an dalam Ritual Rebo Wekasan}

Untuk menganalisa pemaknaan Masyarakat Sukoreno terhadap penggunaan ayat-ayat al-Qur'an dalam ritual Rebo wekasan, penulis menggunakan teori sosiologi pengetahuan Karl Mannheim. Mannheim menyatakan bahwa tindakan manusia dibentuk oleh dua dimensi, prilaku (behaviour) dan makna (meaning). Oleh karena itu, untuk memahami tindakan sosial, ilmuan sosial harus mengkaji antara lain: a) perilaku eksternal, di sini metode ilmiah dapat diterapkan, b) makna perilaku, disini pendekatan hermeneutika diperlukan. Mannheim membagi makna perilaku menjadi tiga macam makna yaitu: Pertama, makna objektif, yang ditentukan oleh konteks sosial dimana tindakan berlangsung. Kedua, makna ekspresive, yang di atributkan pada tindakan aktor. Dan ketiga, makna dokumenter, yang aktor seringkali tersembunyi, mengekspresikan aspek yang menunjuk pada kebudayaan secara keseluruhan. ${ }^{18}$ Ketiga macam makna inilah yang menjadi pijakan penulis dalam membaca pemaknaan masyarakat Sukoreno terhadap penggunaan ayat-ayat al-Qur'an dalam ritual Rebo wekasan.

\section{a. Makna objektif sebagai tradisi}

Makna obyektif dari penggunaan ayat-ayat al-Qur'an dalam ritual Rebo wekasan di Desa Sukoreno adalah sebuah ajaran yang ditanamkan orang terdahulu sehingga berubah menjadi tradisi yang dilakukan setiap hari Rabu terakhir bulan shafar. Fungsinya adalah untuk menolak 320.000 malapetaka yang turun di hari tersebut. Dalam prkatik tersebut digunakan ayat-ayat al-Qur'an di dalamnya. Praktik ritual Rebo

\footnotetext{
${ }^{17}$ Wawancara dengan Bapak Hasyim Asy’ari, tanggal 8 Januari 2014.

18 Gregory Baum, Agama dalam Bayang-bayang Relavitisme (Sebuah Analisis Sosiologi Pengetahuan Karl Mannheim tentang Sintesa Kebenaran Historis-Normatif), terj. Achmad Murtajib Chaeri, (Yogyakarta: Tiara Wacana, 1999), hlm. 16.
} 
wekasan yang dilaksanakan di Desa Sukoreno tercantum dalam kitab Tajwid Madura karangan Abdul Hamid Baqir. Kitab ini digunakan sebagai rujukan pelaksanaan ritual Rebo wekasan di Desa Sukoreno.

Pemahaman masyarakat mengenai Rebo wekasan terbentuk karena adanya jaringan-jaringan intelektual dari ajaran yang ditanamkan orang terdahulu maupun ajaran yang terdapat dalam kitab tajwid madura. Bagitu juga pemahaman mengenai penggunaan ayat-ayat al-Quran yang terdapat dalam ritual tersebut. Bagi penulis, penggunaan ayat-ayat al-Qur'an dalam ritual Rebo wekasan selain bermakna sebagai kepatuhan terhadap ajaran yang dibawa oleh para ulama dengan merujuk kepada kitab Tajwid Madura, dan sebagai tradisi yang dilaksanakan tiap tahun, juga sebagai suatu perantara penolak 320.000 musibah yang turun pada hari rabu terkahir bulan shafar. Maka hal demikian itulah yang menunjukkan makna objektif.

b. Makna ekspresif sebagai penolak bala'

Makna ekspresif atau makna personal yang ditunjukkan oleh pelaku ritual Rebo wekasan terhadap ayat al-Qur'an, penulis bagi menjadi dua pemkanaan yaitu, pemaknaan terhadap ayat al-Qur'an di luar ritual Rebo wekasan dan pemaknaan terhadap ayat al-Qur'an di dalam ritual Rebo wekasan. Untuk mempermudah penulis dalam menemukan makna ekspresif, penulis bagi menjadi tiga katagori yaitu:

1) Makna menurut pimpinan ritual Rebo wekasan

Makna ekspresif penggunaan ayat-ayat al-Qur'an dalam ritual rebo wekasan menurut pemimpin ritual (pak Asy'ari) adalah sebuah ketentuan dari orang yang pertama kali melaksanakan ritual rebo wekasan. Namun pak Asy'ari mempunyai pemahaman tersendiri mengenai ayat-ayat dalam ritual rebo wekasan, yaitu:

Pertama, surat al-Kaus|ar, Pak Asy'ari menyampaikan bahwa:

alasan penggunaan surat al-Kaus|ar dalam shalat tala' bala' adalah sesuai dengan ayat fas\}alli li rabbika (فصلّ لرَبِّكَكَ) yang artinya "maka shalatlah kamu untuk Tuhanmu." Mungkin alasan KH. Abdul Hamid ${ }^{19}$ menggunakan surat alKaus|ar karena terdapat perintah shalat didalamnya. Akan tetapi, pembacaan

\footnotetext{
${ }^{19}$ Pengarang kitab Tajwid Madura.
} 
surat ini hanya anjuran dan kebiasaan saja, boleh diganti dengan surat-surat lain. $^{20}$

Kedua, surat al-Ikhlas. Pak Asy'ari tidak menjelaskan sebab surat al-Ikhlas dimasukkan dalam ritual rebo wekasan, beliau hanya menjelaskan kandungan dan keutamaan surat al-Ikhlas, bahwa kandungan dari surat al-Ikhlas adalah meyakinkan kepada manusia bahwa Allah adalah Esa, yang tertera dalam ayat pertama surat alIkhlas. Kemudian, pak Asy'ari juga menjelaskan keutamaan surat al-Ikhlas dalam hal ini beliau menyebutkan suatu hadis yang berkenaan dengan keutamaan surat al-Ikhlas yaitu:

Nabi Muhammad bersabda kepada Siti Aisyah, "kamu tidak boleh tidur sebelum melakukan empat perkara, yaitu: menghatamkan al-Qur'an, meminta maaf kepada para Nabi, memohonkan ampun orang mukmin, dan melaksankan ibadah haji. Setelah bersabda demikian, Rasulullah kemudian melaksakan shalat, sedangkan Siti Aisyah masih kebingungan dengan pesan yang disampaikan oleh Rasulllah. Seusai Rasulullah shalat, beliau bertanya kepada Siti Aisyah, "mengapa kau terlihat sedih?” Siti Aisyah menjawab "apa yang telah engkau sabdakan terlalu berat bagiku." Rasullah hanya tersenyum sembari menjelaskan maksud dari perkataannya. "bacalah surat al-Ikhlas tiga kali, maka seperti engkau telah menghatamkan al-Qur'an, bacalah shalawat, maka seperti engkau telah meminta maaf kepada para Nabi, kemudian bacalah istigfar (astagfirulla $>$ ha lil mu'mini>na wal mu'mina>t) maka engkau telah memohonkan ampun orang mukmin, dan bacalah kalimat ash-s\}a>lihah (Subha>nallah, walhamdulilla>hi, wa la> ila>ha illalla>llahu, waalla>hu akbar, wa la> haula wa la> quwwata illa> billahi) seperti engkau telah melaksanakan haji."

Dari penjelasan tersebut dapat disimpulkan bahwa surat al-Ikhlas mempunyai beberapa keutamaan diantaranya, dengan membaca surat al-Iklas tiga kali seperti membaca seluruh al-Qur'an. Sayangnya pak Asy'ari hanya menjelaskan hadis secara maknawi tanpa menyertakan lafaz\} matan hadis dan sumber rujukan dari penjelasannya. Pak Asy'ari hanya menjelaskan kandungan dan surat al-Ikhlas diluar ritual rebo wekasan. sedangkan makna surat al-Ikhlas dalam ritual rebo wekasan beliau tidak menjelaskan.

Ketiga, surat muawiz|atain. Menurut pak Asy'ari kandungan surat mu'awwiz|atain adalah untuk membedakan keyakinan orang Islam dan orang musyrik. Sedangkan keutamaan surat muawiz|atain adalah untuk menolak dari niatan orangorang yang ingin berbuat jahat. Salah satu alasan surat muawiz|atain dibaca dalam ritual

\footnotetext{
${ }^{20}$ Wawancara dengan Bapak Hasyim Asy’ari, tanggal 8 Januari 2014.
} 
rebo wekasan adalah untuk meminta perlindungan kepada Allah, khususnya meminta perlindungan dari segala musibah yang turun pada hari rabu terakhir bulan shafar. ${ }^{21}$

Penjelasan di atas, ada kaitanya dengan beberapa hadis yang menerangkan tentang keutamaan surat al-Ikhlas, dan surat muawiz|atain. Salah satunya adalah hadis riwayat An-Nasa'i, nomer 5336:

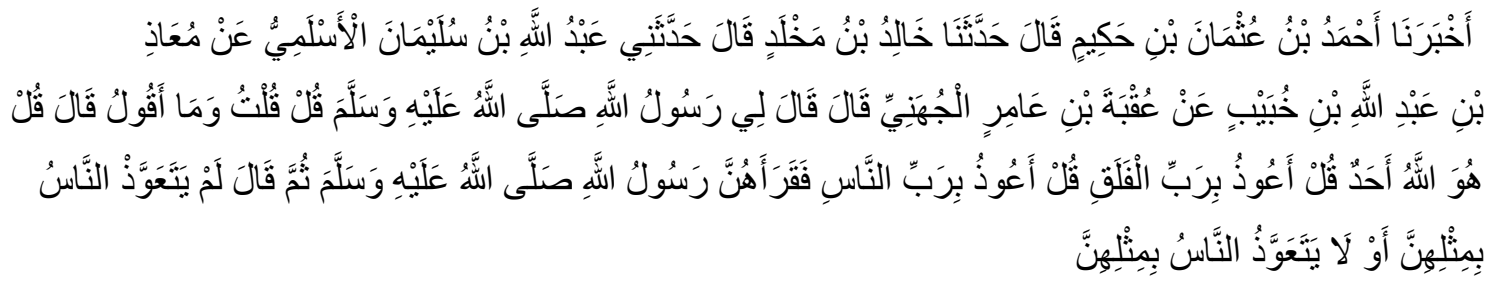

Artinya:

Telah mengabarkan kepada kami Ahmad bin Utsman bin Hakim ia berkata; telah menceritakan kepada kami Khalid bin Makhlad ia berkata; telah menceritakan kepadaku Abdullah bin Sulaiman Al Aslami dari Mu'adz bin Abdullah bin Khubaib dari Uqbah bin Amir Al Juhani ia berkata; "Rasulullah shallallahu 'alaihi wasallam berkata kepadaku: "Katakanlah!" aku bertanya; "Apa yang harus aku katakan?" beliau menjawab: 'Qul hualla>hu ahad' (Katakanlah: "Dia-lah Allah, Yang Maha Esa), 'Qul 'auz|ubirabbil falaq (Katakanlah: "Aku berlindung kepada Tuhan Yang Menguasai subuh) ' dan 'Qul 'auz|ubirabbinna>s (Katakanlah: "Aku berlindung kepada Tuhan (yang memelihara dan menguasai) manusia) '." Rasulullah shallallahu 'alaihi wasallam kemudian membaca ayat-ayat tersebut, setelah itu beliau bersabda: "Manusia tidak akan mendapatkan suatu perlindungan yang semisal dengan ayat-ayat tersebut."22

Keempat, ayat-ayat dalam jimat. Penjelasan potongan-potongan ayat dalam tulisan jimat menurut pak Asy'ari sebagai berikut:

Ayat-ayat yang ditulis dalam jimat merupakan potongan-potongan ayat dari surat-surat al-Qur'an yang maknanya berisi tentang kisah-kisah para Nabi. Alasan pengarang jimat menuliskan ayat-ayat tersebut adalah untuk mengingatkan peristiwa yang menimpa para Nabi, dan mereka diselamatkan oleh Allah, sebab mereka merupakan kekasih Allah yang dekat dengan-Nya. Tujuannya adalah agar kita mencontoh para Nabi, yaitu dengan mendekatkan diri kepada Allah agar selalu mendapatkan pertolongan dari-Nya. Mengenai kalimat قوله الحقّ وله الملك ibarat judul dari jimat tersebut, yang menerangkan bahwa semua kalam Allah adalah benar dan Dia pemilik kekuasaan. ${ }^{23}$

\footnotetext{
${ }^{21}$ Wawancara dengan bapak Hasyim Asy’ari, tanggal 8 Januari 2014.

${ }^{22}$ An-Nasa'i, Sunan An-Nasa'i, Kitab al-Isti'a>zah, dalam CD Rotm Lidwa 9 Kitab Imam.

${ }^{23}$ Wawancara dengan bapak Hasyim Asy’ari, tanggal 8 Januari 2014.
} 
Demikianlah, makna ekspresif yang diutarakan oleh pak Asy'ari selaku pemimpin ritual rebo wekasan terkait penggunaan al-Qur'an dalam ritual Rebo wekasan. Dari penjelasan diatas dapat disimpulkan bahwa, setiap ayat al-Qur'an yang terdapat dalam ritual Rebo wekasan mempunyai tujuan dan faidah tersendiri.

2) Makna menurut santri pak Asy'ari yang mengikuti ritual Rebo wekasan secara utuh

Setelah dilakukan wawancara langsung kepada sebagian santri pak Asy’ari yang mengikuti ritual Rebo wekasan dengan utuh (melaksankan shalat tala'bala' dan membuat dan meminum air jimat), maka diperoleh makna penggunaan ayat-ayat alQur'an dalam ritual rebo wekasan sebagai berikut:

a) M. Yusri Zaini, kelas 1 Aliyah menuturkan:

Pada awalnya, saya hanya ikut-ikutan melaksanakan ritual rebo wekasan, setelah saya tau tujuanRrebo wekasan dan setelah mengetahui adanya bukti dari cerita pak Asy'ari, maka saya semakin percaya akan khasiat Rebo wekasan. Bagi saya, mengerjakan ritual rebo wekasan harus lengkap (melaksanakan shalat tala' bala' dan membuat serta meminum air jimat) tidak boleh setengah-setengah. Jika hanya meminum air jimat tanpa melaksanakan shlat tala' bala' menurut saya kurang afd \}ol.

Adapun makna penggunaan ayat-ayat al-Qur'an dalam ritual Rebo wekasan, menurut Yusri Zaini ;

pembacaan surat-surat al-Qur'an dan tulisan surat al-Qur'an dalam ritual rebo wekasan merupakan ketentuan dari ulama terdahulu dan sudah lama dilakukan oleh para alim ulama. Tentunya para ulama tidak mungkin asal-asalan mengambil surat dan ayat al-Qur'an. Mereka pasti sudah mengetahui makna dan kandungan dari ayat tersebut. Kita tau bahwa ulama terdahulu sebelum menentukan sesuatu harus tirakat dulu, jadi tidak mungkin jika mereka asal mengambil ayat al-Qur'an. Saya pernah mendengar ceramah dari Gus Dur, kata beliau 'al-Qur'an itu jimatnya banyak, jadi tidak usah memakai kalimat-kalimat lain, cukup mengunakan al-Qur'an saja, jimat paling ampuh adalah jimat menggunakan ayat al-Qur'an.”

M. Yusri Zaini memaknai al-Qur'an di luar ritual Rebo wekasan adalah sebagai bacaan yang jika membacanya mendapat banyak pahala. Sedangkan penggunaan ayat- 
ayat al-Qur'an di dalam ritual Rebo wekasan merupakan ketentuan dari ulama terdahulu, dan setiap ayat yang digunakan mempunyai khasiat tersendiri. ${ }^{24}$

b) Jamaluddin, kelas 2 SMP:

Saya baru tiga kali mengikuti ritual Rebo wekasan, selain anjuran dari langgar, ${ }^{25}$ juga perintah dari orang tua, orang tua saya yang selalu menyuruh saya untuk mengikutinya tiap hari Rebo wekasan. saya tau dalam jimaT terdapat tulisan ayat al-Qur'an, tetapi saya tidak tau artinya apa. Akan tetapi setiap selesai melaksanakan shalat tala' bala' dan meminum air jimat saya merasa lebih nyaman. ${ }^{26}$

Makna ekspresif dari yang diutarakan Jamaluddin adalah dengan melaksanakan shalat tala' bala' dan meminum air jimat maka akan mendapatkan ketenangan. Akan tetapi dia tidak mengetahui makna dan khasiat dari ayat yang dipakai dalam ritual tersebut.

c) Lutfiatin, santri pak Asy'ari, kelas 2 SMP:

Setiap ada ritual Rebo wekasan saya pasti ikut, meskipun saya tidak dalam keadaan suci dan tidak bisa melaksanakan shalat tala' bala' saya tetap datang ke langgar untuk mengikuti doa bersama dan meminta air jimat. Kalau tidak mengikuti ritual tersebut, saya merasa takut tertimpa bala' yang turun di hari Rebo wekasan. ${ }^{27}$

Makna ekspresif yang diungkapkan Lutfiatin adalah satu kepercayaan yang apabila ditinggalkan timbul rasa khawatir dan takut terhadap musibah yang diturunkan pada hari Rebo wekasan.

3) Makna menurut masyarakat yang hanya mengikuti praktk pembuatan jimat.

a) ibu Misnaya, seorang pedagang, menuturkan:

Air jimat itu ditulisi dengan tulisan $\mathrm{Arab}^{28}$, saya percaya bahwa tulisan Arab itulah yang menjadi perantara untuk menjauhkan kita dari segala musibah yang turun, dan Alhamdulillah dengan minum air jimat, saya tidak mengalami apa pun yang berhubungan dengan musibah. Selain diminum, saya juga meleburkan

\footnotetext{
${ }^{24}$ Wawancara dengan M. Yusri Zaini.

${ }^{25}$ Langgar adalah surau/mushalla tempat para santri mengaji

${ }^{26}$ Wawancara dengan Jamaluddin, pada tanggal 2 Januari 2014.

${ }^{27}$ Wawancara dengan Lutfiatin, pada tanggal 1 Januari 2014.

${ }^{28}$ Mayoritas mayarakat Sukoreno menyebut tulisan al-Qur'an dengan tulisan Arab.
} 
air tersebut kedalam sumur agar setiap air yang saya gunakan memperoleh khasiat dari air jimat. ${ }^{29}$

Makna ekspresif yang diungkapkan ibu Misnanya mengenai penggunaan ayat alQur'an dalam tradisi Rebo wekasan adalah ayat yang terdapat di dalam jimat mempunyai khasiat menjauhkan dari musibah yang turun pada hari tersebut.

b) Pak Erfan, kepala desa Sukoreno mengatakan:

Air jimat itu dicampuri tulisan al-Qur'an, maka tulisan al-Qur'an itu sebagai perantara untuk menolak musibah. Biasanya al-Qur'an kan berkhasiat untuk menyembuhkan penyakit, jadi al-Qur'an itu cuma sebagai perantara agar diselamatkan dari musibah. Para ulama tentunya memiliki alasan mengapa mengambil ayat-ayat tertentu, karena mereka merupakan orang-orang berilmu yang dekat dengan Allah. Kalau masalah rasa, sebenarnya rasa air jimat sama dengan air biasa, tapi karena kita sudah percaya, jadinya saya merasa lebih nyaman saja, mungkin keyakinan itu yang membuat kita nyaman setelah minum air jimat. ${ }^{30}$

Ada tiga poin makna ekspresif yang diungkapkan oleh pak Erfan yaitu, pertama, makna ekspresif pak Erfan tentang penggunaan ayat al-Qur'an di luar ritual Rebo wekasan adalah mempunyai khasiat sebagai penyembuh penyakit. Kedua, ayat-ayat alQur'an dalam ritual Rebo wekasan adalah sebagai perantara atau sarana untuk menolak musibah yang turun pada hari tersebut. Ketiga, ayat al-Qur'an yang digunakan dalam ritual Rebo wekasan merupakan ketentuan dari ulama terdahulu yang diyakini bahwa sesuatu yang dibawa oleh para ulama pasti membawa kebaikan.

c) Ibu Sauda, seorang petani:

Al-Qur'an itu kan kalam Allah, jadi tidak mungkin mengandung kejelekan. Jadi sesuatu apapun yang ada ayat al-Qur'annya pasti mengandung banyak kebaikan. Air jimat dalam ritual Rebo wekasan berkhasiat menolak bala' yang turun. Saya tidak hanya meminum air jimat, saya juga mencampurkan ke dalam sumur dan kamar mandi dan bahkan jika masih ada sisa air jimat saya campurkan ke dalam air untuk mengairi sawah, konon sawah bisa terbebas dari hama. ${ }^{31}$

Pemaknaan ibu Sauda terhadap al-Qur'an di luar ritual Rebo wekasan adalah kalam Allah yang mengandung banyak manfaat. Dan penggunaan ayat-ayat al-Qur'an setelah masuk ke dalam ritual Rebo wekasan menurutnya adalah berkhasiat menolak

\footnotetext{
${ }^{29}$ Wawancara dengan Ibu Misnaya.

${ }^{30}$ Wawancara dengan bapak Erfan Sahrianto,tanggal 2 Januari 2014.

${ }^{31}$ Wawancara dengan ibu Sauda, seorang petani sekaligus pelaksana ritual rebo wekasan, di Sukoreno tanggal 4 Januari 2014.
} 
bala'. Baginya, air jimat tidak hanya berkhasiat untuk manusia melainkan untuk mahluk lain seperti hewan dan tumbuhan.

Demikian makna ekspresif dari masing-masing pelaku ritual Rebo wekasan. setiap orang mempunyai pemahaman dan pemaknaan tersendiri mengenai penngunaan ayat al-Qur'an dalam ritual Rebo wekasan, akan tetapi kebanyakan dari mereka berpendapat bahwa penggunaan ayat al-Qur'an tersebut adalah untuk menolak bala' yang turun pada rabu terakhir bulan shafar.

c. Makna dokumenter sebagai suatu kebudayaan

Sebagaimana disebutkan di atas bahwa makna dokumenter adalah makna yang tersirat atau tersembunyi, sehingga aktor atau pelaku suatu tindakan tersebut, tidak sepenuhnya menyadari bahwa suatu aspek yang diekspresikan menunjukkan kepada kebudayaan. Penulis mencoba menunjukkan bahwa penggunaan ayat-ayat al-Qur'an dalam ritual Rebo wekasan di Desa Sukoreno pada awalnya merupakan suatu doktrin yang ditanamkan oleh ulama terdahulu, dengan karakteristik masyarakat Desa Sukoreno yang sam'an wa t;a'atan terhadap para ulama atau tokoh masyarakat menjadikan pengunaan ayat-ayat al-Qur'an dalam ritual Rebo wekasan di Desa Sukoreno menjadi suatu tradisi. Hampir seluruh masyarakat pelaksana ritual Rebo wekasan, sedikit atau banyak memiliki pemahaman adanya manfaat yang terkandung dari ayat-ayat al-Qur'an yang digunakan dalam ritual tersebut.

Demikian pula di masyarakat secara umum, terlebih lagi bagi masyarakat yang sudah terbiasa menggunakan ayat-ayat al-Qur'an seperti sebagai terapi pengobatan, untuk mendatangkan kekuatan magis (supranatural), maupun dalam acara tradisi-tradisi dan adat-istiadat lain, seperti peringatan tujuh bulan kehamilan, maupun acara-acara yang lainnya, maka ketika di dalamnya dilaksanakan pembacaan ayat-ayat al-Qur'an maupun surat-surat pilihan, hal tersebut disadari atau tidak, adalah merupakan suatu praktik pembacaan al-Qur'an yang telah menjadi kebudayaan yang menyeluruh.

\section{E. Wujud Resepsi Penggunaan Ayat al-Qur’an dalam Ritual Rebo Wekasan}

Pemahaman masyarakat Sukoreno mengenai ayat al-Qur'an dalam ritual Rebo wekasan merupakan resepsi hermeneutis sekaligus resepsi kultural terhadap ayat-ayat 
yang digunakan dalam ritual Rebo wekasan. Adapun ayat yang hidup dalam ritual Rebo wekasan adalah surat al-Kausar, al-Ikhlas, al-Falaq, an-Nas dan potongan-potongan ayat yang terdapat pada jimat seperti yang telah penulis jelaskan di atas. Sedangkan ayat yang melatar belakangi dilaksanakannya ritual Rebo wekasan tercantum dalam surat alQamar: 19 yang kemudian dikuatkan oleh hadis yang diriwayatkan oleh Abu Daud no. 3414.

Adapun resepsi hermeneutis penggunaan ayat al-Qur'an dalam ritual Rebo wekasan adalah seperti yang terungkap dalam makna ekspresif di atas. Yaitu makna ekspesif bagi pemimpin ritual maupun bagi pelaksana ritual. Resepsi hermeneutis bagi pemimpin ritual mengenai ayat-ayat yang digunakan dalam ritual rebo wekasan, bahwa setiap ayat yang terdapat dalam ritual mempunyai faidah dan keutamaan tersendiri. Misal dalam surat al-Kausar. Menurut pemimpin ritual mengapa surat al-Kausar dijadikan sebagai surat yang dibaca pada shalat tala' bala' karena dalam surat tersebut terdapat ayat فصلَّ رِربِّكَ

Resepsi kultural masyarakat Sukoreno terhadap penggunaan ayat al-Qur'an dalam ritual Rebo wekasan dilihat dari tiga sistem, yaitu: sistem gagasan atau kepercayaan, sistem sosial, dan artifak. Adapun sistem kepercayaan masyarakat Sukoreno, bahwa ayat al-Qur'an yang digunakan dalam ritual Rebo wekasan sebagai penolak bala' dan mereka meyakini bahwa ayat al-Qur'an tersebut mampu menolak bala' yang turun pada hari rabu terakhir di bulan shafar.

Sedangkan sistem sosialnya dapat dilihat dari pola prilaku masyarakat Sukoreno ketika pelaksanaan ritual Rebo wekasan. masyarakat Sukoreno berbondong-bondong untuk mengambil air jimat untuk diminum. Selain meminum air tersebut, masyarakat juga memmasukkannya ke tempat-tempat air, misal kendi, sumur, kamar mandi dan lain sebagainya. Sebagaimana kepercayaan mereka bahwa air jimat tersebut dapat menolak bala' yang turun. Adapun beberapa artifak yang digunakan dalam ritual Rebo wekasan adalah piring porselen putih dan spidol sebagai alat untuk menuliskan jimat, dan ember besar sebagai wadah air untuk menampung air jimat.

\section{F. Kesimpulan}

Ritual Rebo wekasan dilaksanakan setiap satu tahun sekali pada hari rabu terakhir bulan Shafar. Tujuan dilaksanakannya ritual tersebut adalah untuk menolak 
musibah yang turun pada hari rabu terakhir bulan Shafar. Sebagaimana dijelaskan dalam kitab Tajwid Madura, Allah menurunkan 320.000 malapetaka pada hari rabu terakhir bulan Shafar. Barang siapa yang menunaikan shalat sebanyak empat raka'at, dan tiap raka'at setelah membaca surah al-fatihah, membaca surat al-Kaus|ar sebanyak tujuh belas kali, kemudian surat al-Ikhlas sebanyak lima kali, serta surat al-Fala>q dan an-Na>s satu kali, kemudian membaca do'a dan membuat jimat. Maka Allah akan melindunginya dari malapetaka yang turun pada hari tersebut.

Adapun proses ritual adalah melaksanakan shalat tala'bala' empat rakaat, berdoa bersama, dan membuat jimat. Sedangkan enggunaan ayat-ayat al-Qur'an, terletak pada dua pelaksanaan; pertama, dalam shalat tala' bala' dibacakan empat surat didalamnya, yaitu surat al-Kaus|ar, surat al-Ikhlas, surat al-Fala>q dan surat an-Nas. Kedua, dalam tulisan jimat, terdapat potongan-potongan ayat al-Qur'an yaitu Surat Yasin ayat 58, Surat Al-Shaffat ayat 79-80, Surat Al-Shaffat ayat 109-110, Surat AlShaffat ayat 130-131, Surat Az-Zumar ayat 73, Surat Al-Ra'd ayat 24, dan Surat AlQadr ayat 5.

Mengenai fungsi dan makna yang terkandung dalam penggunaan ayat-ayat alQur'an dalam ritual Rebo wekasan jika dilihat dari teori sosiologi pengetahuan Karl Mannheim, terdapat tiga katagori makna, yaitu makna obyektif, makna ekspresive dan makna dokumenter. Makna objektif penggunaan ayat al-Qur'an dalam ritual Rebo wekasan adalah sebagai tradisi. Sedangkan makna ekspresif, setiap individu mempunyai pendapat yang berbeda-beda, namun bagi sebagian besar masyarakat penggunaan ayatayat al-Qur'an dalam ritual Rebo wekasan adalah sebagai penolak bala'. Terakhir, makna dokumenter dari penggunaan ayat-ayat al-Quran dalam ritual Rebo wekasan ini sesungguhnya dapat diketahui jika diteliti secara mendalam, karena makna dokumenter tersebut adalah makna yang tersirat dan tersembunyi, yang secara tidak disadari bahwa dari satu praktik penggunaan ayat-ayat al-Qur'an ini bisa menjadi suatu kebudayaan yang menyeluruh.

Penjelasan di atas menunjukkan fenomena pola-pola prilaku masyarakat Islam yang muncul dari pemahaman mereka terhadap teks-teks al-Qur'an. Al-Qur'an tidak lagi sesuatu yang diam (silent) dan tertulis (written) dalam lembaran-lembaran mushaf. Al-Qur'an di sini adalah apa yang dipraktikkan dan dimanifestasikan dalam kehidupan 
masyarakat Islam. fenomena ini yang dalam ilmu al-Qur'an disebut dengan living Qur'an. Living Qur'an pada ritual Rebo wekasan merupakan suatu resepsi masyarakat Sukoreno terhadap al-Qur'an. Inti dari resepsi adalah bagaimana seorang muslim membaca dan menerima al-Qur'an untuk kemudian merespon al-Qur'an itu.

Resepsi yang ditunjukkan oleh masyarakat Sukoreno terhadap penggunaan ayat al-Qur'an dalam ritual rebo wekasan termasuk dalam resepsi hermeneutis sekaligus kultural. Yaitu setiap pelaksana ritual memiliki pemahaman dan penafsiran tersendiri terhadap ayat-ayat yang digunakan dalam ritual Rebo wekasan. Selain itu, ritual ini menunjukkan suatu resepsi yang berkaitan erat dengan budaya lokal Indonesia yang kemudian diakulturasikan dengan budaya baru yang dibawa oleh Islam, yaitu dengan mencantumkan atau menggunakan ayat-ayat al-Qur'an dalam ritual tersebut, seperti dalam shalat tala' bala' dan pembuatan jimat. 


\section{Daftar Pustaka}

Baum, Gregory. Agama dalam Bayang-bayang Relavitisme (Sebuah Analisis Sosiologi Pengetahuan Karl Mannheim tentang Sintesa Kebenaran Historis-Normatif), terj. Achmad Murtajib Chaeri. Yogyakarta: Tiara Wacana, 1999.

Essack, Farid. The Qur'an A Short Introduction. London: One World Publication. 2002.

Hadikusuma, Hilman. Antropologi Agama. Bandung: Citra Aditya Bakti, 1993.

Hamid Baqir, Abdul. Ringkasan terjemah dari karangan KH. Abdul Hamid bin Isbat. Madura: Dar al-Taqafi, 1980.

M. Federspeil, Howard. Kajian al-Qur'an di Indonesia. Yogyakarta: Mizan, 1996.

Mannheim, Karl. Idiologi dan Utopia (Menyingkap Kaitan Pikiran dan Politik), terj. F. Budi Hardiman. Yogyakarta: Kanisius, 1991.

P. Spradley, James. Metode Etnografi, terj. Misbah Zulfa Elizabeth. Yogyakarta: PT. Tiara Wacana, 1997.

Purwadi. Ensiklopedi adat istiadat Budaya Jawa. Yogyakarta: SHAIDA. 2007.

Qudsi, Abdul Hamid bin Muhammad Ali. Kanzun Najah. Makkah: Mathba'ah AtTaraqqil Majidiyah al-'Utsmaniyah. 1330.

Wawancara dengan bapak Hasyim Asy'ari sebagai pemimpin ritual rebo wekasan, di Sukoreno tanggal 1 Januari 2014.

Wawancara dengan Ibu Misnaya, sebagai pelaku ritual rebo wekasan tanggal 1 Januari 2014.

Wawancara dengan ibu Sauda, seorang petani sekaligus pelaksana ritual rebo wekasan, di Sukoreno tanggal 4 Januari 2014.

Wawancara dengan Jamaluddin, siswa kelas 2 SMP yang merupkan santri pak Asyari, di Sukoreno tanggal 2 Januari 2014.

Wawancara dengan M. Yusri Zaini, sebagai santri pak Asy'ari sekaligus pelaku ritual rebo wekasan, di Sukoreno tanggal 2 Januari 2014.

Wawancara dengan Pak Erfan Sahrianto, selaku kepala Desa Sukoreno tanggal 2 Januari 2014.

Wawancara dengan Nailur Rahman, alumni P.P. Banyu Anyar Pamekasan Madura, diYogyakarta, tanggal 3 Juni 2014. 